\title{
Effect of Feeding of Raw Winged Bean Seeds on Gastrointestinal Functions in Rats
}

\author{
Toshizo Kimura, Chirawat SAtanachote, and Akira YoshidA ${ }^{1}$ \\ Laboratory of Nutritional Biochemistry, Department of Agricultural \\ Chemistry, Nagoya University, Chikusa-ku, Nagoya 464, Japan
}

(Received April 27, 1981)

\begin{abstract}
Summary The primary cause of the adverse effects of feeding of raw winged bean seeds in rats was investigated. In experiment 1 , rats were fed on either a raw winged bean diet or a steamed winged bean diet for 10 days. Body weight gain of rats fed on $30 \%$ raw winged bean diet was significantly lower than that of rats fed on $30 \%$ steamed winged bean diet. The adverse effect of the feeding of $30 \%$ raw winged bean diet on growth was accompanied by disorders of the gastrointestinal tract including a significant reduction in intestinal sucrase activity, not being improved with feeding of the diet supplemented with methionine. In experiment 2 , rats fasted for 2 days were refed on a $10 \%$ casein diet, a $30 \%$ raw winged bean diet or a $30 \%$ steamed winged bean diet, in which most of the carbohydrate component was sucrose, for 4 days. Although body weight gain and food consumption in rats refed on these winged bean diets were lower than those in rats refed on $10 \%$ casein diet, the effects of feeding of the raw winged bean diet on body weight gain and food consumption were extremely deleterious as compared with those of feeding of the steamed winged bean diet. Significant reductions in hydrolase activities localized in the brush border membrane of the small intestine were found in rats refed on the raw winged bean diet prior to the occurrence of apparent disorders in the gastrointestinal tract. These findings suggest that the primary cause of the adverse effects of raw winged bean seed feeding is disorders in the small intestine caused by lectin or similar substances in raw winged bean seeds.
\end{abstract}

Key Words winged bean, lectin, small intestine, sucrase, alkaline phosphatase, leucine aminopeptidase

The winged bean (Psophocarpus tetragonolobus) seems to be a crop with nutritional potential $(1,2)$. Protein, lipid, mineral and vitamin components of winged bean seeds were similar to those of soybean. The diets prepared with the ground raw seeds were toxic to rats, and the activity of trypsin inhibitor, amylase

1 木村利三, 吉田 昭 
inhibitor and lectin in the raw seeds was detected, whereas the diets prepared with the cooked seeds caused fairly good growth in rats, and activities of these substances were destroyed entirely by heat-cooking (2). On the other hand, feeding of a raw soybean diet to rats caused significant growth retardation, but the adverse effect was improved by the addition of methionine to the $\operatorname{diet}(3,4)$. In a preliminary experiment in our laboratory, we found that feeding of a raw winged bean meal diet to rats produced remarkable growth retardation and a reduction in food consumption along with significant apparent disorders of the gastrointestinal tract. And these deteriorating effects were not entirely prevented by the addition of methionine to the diet. These findings suggested that the deleterious effects of the raw winged bean meal diet were caused by some toxic factors in raw winged bean seeds with the exception of trypsin inhibitor. The present study was undertaken to investigate the primary toxic factors in raw winged bean seeds through the effects of raw winged bean seed feeding to rats on the intestinal enzyme activities localized in the brush border membrane of the small intestine (5).

\section{EXPERIMENTAL}

Male rats of the Wistar strain (Shizudokyo, Shizuoka, Japan) were individually housed in suspended wire-mesh cages in a room kept at $23-25^{\circ} \mathrm{C}$ with lighting automatically regulated to provide a $12-\mathrm{hr}$ light period $(0800-2000 \mathrm{hr})$ and a $12-\mathrm{hr}$ dark period $(2000-0800 \mathrm{hr})$. Dried raw winged bean seeds produced in the Philippines were ground into meal which contained $32.2 \%$ of protein $(\mathrm{N} \times 6.25)$. The steamed winged bean meal was prepared by exposing the raw winged bean meal to 15 -pounds pressure $\left(120^{\circ} \mathrm{C}\right)$ for $30 \mathrm{~min}$.

Experiment 1. Rats weighing 40 to $50 \mathrm{~g}$ were used, and the experimental diets were $30 \%$ raw and steamed winged bean diets. The composition of the $30 \%$ raw winged bean diet was in percent: raw winged bean meal, 30; corn oil, 5; salt mixture (6), 4; vitamin mixture (7), 2; choline chloride, 0.2 ; and starch-sucrose (2:1) mixture, 58.8. Retinyl palmitate, 3,500 IU; ergocalcipherol, $350 \mathrm{IU}$; and all-rac- $\alpha-$ tocopherol, $5 \mathrm{mg}$ were added to $100 \mathrm{~g}$ of the diet. The composition of the $30 \%$ steamed winged bean diet was similar to that of the $30 \%$ raw winged bean diet except for the replacement of raw meal with steamed meal. A 30\% raw winged bean plus methione diet was made by the addition of L-methionine at the $0.3 \%$ level to the $30 \%$ raw winged bean diet. Rats were fed ad libitum one of these winged bean diets for 10 days, being killed in the morning on day 11 . The small intestine was rapidly removed, a jejunal segment representing the second $15 \mathrm{~cm}$ segment distal to the pylorus being excised. The segment was slit longitudinally after rinsing with cold saline, and was homogenized with cold water in a Polytron homogenizer (model PCO-2-110 Kinematica, Switzerland). The resulting homogenate was used for the determinations of protein content and sucrase activity.

Experiment 2. Rats weighing approximately $100 \mathrm{~g}$ were used. The experimental diets were $10 \%$ casein, $30 \%$ raw winged bean, and $30 \%$ steamed winged bean. 
The composition of the $10 \%$ casein diet was in percent: casein, 10; corn oil, 5; salt mixture (6), 4; vitamin mixture(7), 2; choline chloride, 0.2; L-methionine, 0.3; starch, 20; and sucrose 58.5. Retinyl palmitate, 3,500 IU; ergocalcipherol, $350 \mathrm{IU}$; and all-rac- $\alpha$-tocopherol, $5 \mathrm{mg}$ were added to $100 \mathrm{~g}$ of the diet. Compositions of the $30 \%$ raw and steamed winged bean diets were in percent: raw winged bean meal or steamed winged bean meal, 30; sucrose, 58.5; and the remainder, except for starch, similar to that of $10 \%$ casein diet. These experimental diets contained about $9 \%$ of crude protein $(\mathrm{N} \times 6.25)$. Rats were divided into three groups after a 2-day fast, and were refed ad libitum on one of these experimental diets for 4 days. They were killed in the morning on day 5 of the refeeding period. The small intestine was rapidly removed, being treated in a manner similar to that used in experiment 1 .

Sucrase activity was determined by the method of Dahlqvist (8). Alkaline phosphatase activity was measured by the method of Kind and King (9). Leucine aminopeptidase activity was determined by the method of Goldbarg and Rutenburg (10), and the determination of the protein content in the small intestine was made by the method of Lowry et al.(11) using bovine serum albumin as a standard. Statistical analysis was done by the least significant difference calculated according to the method described by Snedecor and Cochran(12).

\section{RESULTS AND DISCUSSION}

The results of experiment 1 are given in Figs. 1 and 2. The body weight gain of rats fed on $30 \%$ raw winged bean diet was clearly lower than that of rats fed on $30 \%$ steamed winged bean diet, and the adverse effect of feeding of $30 \%$ raw winged bean diet on growth was not improved with feeding of the diet supplemented with $0.3 \%$ of L-methionine. There were differences in food consumption similar to those in body weight gain among rats fed on these experimental diets. Intestinal sucrase

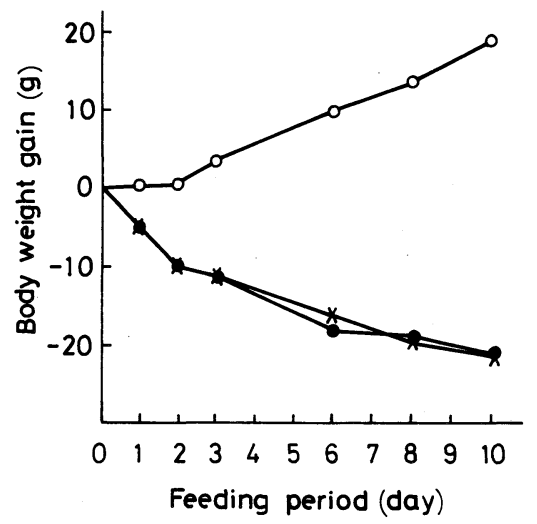

Fig. 1. Changes in body weight gain of rats fed on winged bean diets. (Experiment 1) $O$, steamed winged bean diet; $\bullet$, raw winged bean diet; $\times$, raw winged bean diet supplemented with $0.3 \%$ of L-methionine.

Vol. 28, No. 1, 1982 




Fig. 2. Effect of feeding of winged bean diets on intestinal sucrase activity in rats. (Experiment 1) RWB, RWB + Met, and SWB indicate the raw winged bean diet, the raw winged bean diet supplemented with $0.3 \%$ of $\mathrm{L}$-methionine, and the steamed winged bean diet respectively. S.I. and $U$ mean the small intestine and micromoles of substrate split per hour, respectively. Vertical bars represent SE of the mean for five rats.

activity per $15 \mathrm{~cm}$ of the small intestine - the segmental sucrase activity-in rats fed on $30 \%$ raw winged bean diet with or without supplemented methionine was significantly decreased as compared with that in rats fed on $30 \%$ steamed winged bean diet. The significant reduction in the segmental sucrase activity was accompanied with remarkably apparent disorders of the gastrointestinal tract, diarrhea or constipation. Table 1 indicates the results of experiment 2 . Body weight gain and food consumption of rats refed on $30 \%$ steamed winged bean diet were clearly higher than those of rats refed on $30 \%$ raw winged bean diet, although body weight gain and food consumption of rats refed on either $30 \%$ raw winged bean diet or $30 \%$ steamed winged bean diet were significantly lower than those of rats refed on $10 \%$ casein diet. The differences similar to those in body weight gain and food consumption among these three groups were found in intestinal enzyme activities, especially the segmental enzyme activities. The adverse effect of feeding of the diet containing raw winged bean meal on growth and food consumption observed in experiment 1 was again found during the early stage of the feeding. Although the apparent disorders in gastrointestinal functions in rats refed on the raw winged bean diet were not observed in experiment 2, their intestinal enzyme activities were significantly lower than those in rats refed on the casein diet. The significant reductions in the enzyme activities was suggested to be the primary cause of the adverse effects including the gastrointestinal disorders due to feeding of the raw winged bean diet, and to be produced by heat-labile constituents - some proteins- 
Table 1. Effect of winged bean diets on intestinal enzyme activities in refed rats. (Experiment 2)

\begin{tabular}{cccc}
\hline Diet & $10 \%$ Casein & $\begin{array}{c}30 \% \text { Raw } \\
\text { winged bean }\end{array}$ & $\begin{array}{c}30 \% \text { Steamed } \\
\text { winged bean }\end{array}$ \\
\hline Initial body wt. (g) & $98.4 \pm 2.3^{1, \mathrm{a}}$ & $98.4 \pm 2.7^{\mathrm{a}}$ & $99.2 \pm 2.2^{\mathrm{a}}$ \\
Changes in body wt. (g/4-day) & $19.4 \pm 1.1^{\mathrm{a}}$ & $-4.4 \pm 0.5^{\mathrm{b}}$ & $2.8 \pm 1.0^{\mathrm{c}}$ \\
Food intake (g/day) & $11.9 \pm 0.4^{\mathrm{a}}$ & $6.6 \pm 0.5^{\mathrm{b}}$ & $8.3 \pm 0.4^{\mathrm{c}}$ \\
Liver wt. (g) & $5.95 \pm 0.20^{\mathrm{a}}$ & $3.28 \pm 0.14^{\mathrm{b}}$ & $3.69 \pm 0.08^{\mathrm{b}}$ \\
Small intestine (S.I.) & & & \\
(mg/segment $\left.{ }^{2}\right)$ & $720 \pm 39^{\mathrm{a}}$ & $576 \pm 31^{\mathrm{b}}$ & $602 \pm 18^{\mathrm{b}}$ \\
S.I. protein & & & \\
(mg/g S.I.) & $199 \pm 7.3^{\mathrm{a}}$ & $164 \pm 5.7^{\mathrm{b}}$ & $195 \pm 14.4^{\mathrm{a}}$ \\
(mg/segment) & $142.0 \pm 4.3^{\mathrm{a}}$ & $94.4 \pm 5.6^{\mathrm{b}}$ & $117.4 \pm 8.9^{\mathrm{c}}$ \\
Sucrase activity & $637 \pm 17^{\mathrm{a}}$ & $230 \pm 30^{\mathrm{b}}$ & $594 \pm 67^{\mathrm{a}}$ \\
(U/g S.I.) & $3.22 \pm 0.11^{\mathrm{a}}$ & $1.41 \pm 0.19^{\mathrm{b}}$ & $3.18 \pm 0.60^{\mathrm{a}}$ \\
(U/mg protein) & $467 \pm 17^{\mathrm{a}}$ & $132 \pm 18^{\mathrm{b}}$ & $356 \pm 38^{\mathrm{c}}$ \\
(U/segment) & & & \\
Alkaline phosphatase activity & $5,737 \pm 782^{\mathrm{a}}$ & $1,896 \pm 180^{\mathrm{b}}$ & $4,011 \pm 730^{\mathrm{c}}$ \\
(U/g S.I.) & $28.6 \pm 3.7^{\mathrm{a}}$ & $11.7 \pm 1.2^{\mathrm{b}}$ & $21.2 \pm 4.1^{\mathrm{a}}$ \\
(U/mg protein) & $4,125 \pm 634^{\mathrm{a}}$ & $1,077 \pm 84^{\mathrm{b}}$ & $2,377 \pm 383^{\mathrm{c}}$ \\
(U/segment) & & & \\
(Uminopeptidase activity & $873 \pm 50^{\mathrm{a}}$ & $369 \pm 50^{\mathrm{b}}$ & $729 \pm 26^{\mathrm{c}}$ \\
(U/g S.I.) & $6.25 \pm 0.11^{\mathrm{a}}$ & $2.27 \pm 0.34^{\mathrm{b}}$ & $3.79 \pm 0.19^{\mathrm{a}}$ \\
(U/mg protein) & $602 \pm 14^{\mathrm{a}}$ & $210 \pm 28^{\mathrm{b}}$ & $439 \pm 24^{\mathrm{c}}$ \\
\hline (U/segment) & &
\end{tabular}

${ }^{1}$ Mean \pm SE $(n=5)$; means within line not sharing a common superscript letter differ significantly $(p<0.05)$. ${ }^{2}$ Second $15 \mathrm{~cm}$ segment from the pylorus. ${ }^{3}$ Micromoles of substrate split per hour.

in raw winged bean seeds, since the adverse effects were remarkably improved in rats refed on the steamed winged bean diet.

We recently reported that the segmental sucrase activity in rats fed on a high sucrose diet was affected by the quality and quantity of dietary proteins (13-15), and that the activities were maintained at a constant level, regardless of food consumption, if animals ate the same $\operatorname{diet}(13-17)$. And a significant reduction or inhibition of intestinal sucrase activity induced gastrointestinal disorders following nutritional disorders throughout the whole body (17-20). The segmental alkaline phosphatase and leucine aminopeptidase activities, however, are known to be affected not only by quality but also the quantity of the diet consumed $(13,14,17)$. From these findings the segmental sucrase activity has been adopted as a suitable criterion for assessing the integrity of functions in the small intestine. On the basis of the consideration mentioned above, the effect of toxic constituents in the raw winged bean seeds on gastrointestinal functions was considered to be reflected in substantial reductions in the segmental sucrase activity. 
On the other hand, the toxic constituents in the raw winged bean seeds were assumed to be the lectin fractions for the following reasons. 1) The adverse effects of feeding of the raw winged bean diet were eliminated by replacing the raw winged bean meal with the steamed winged bean meal. 2) As the adverse effects were not prevented by the addition of methionine to the raw winged bean diet, the toxic constituents were suggested to be others, with the exception of trypsin inhibitor $(3,4,21) .3)$ Since feeding of the raw winged bean diet containing sucrose as the greatest carbohydrate source induced the adverse effects, the amylase inhibitor was not considered to be a main factor of the toxic components. 4) Feeding of the diet supplemented with beans containing high lectin activities caused a disruption of the brush border membrane in the small intestine, followed by significant growth retardation (22).

To verify the hypothesis, however, the relationships between the feeding of a diet containing lectin fractions isolated from raw winged bean seeds and intestinal sucrase activity in rats are required to be extensively investigated, and attempts to find confirmable evidence lending support to the hypothesis are in progress in our laboratory.

\section{REFERENCES}

1) Černý, K., Kordylas, M., Pospíšil, F., Švápenský, O., and Zajíc, B. (1971): Nutritive value of the winged bean (Psophocarpus palustris Desv.). Br. J. Nutr., 26, 293-299.

2) Jaffé, W. G., and Kortes, R. (1976): Nutritional characteristics of the winged bean in rats. Nutr. Rep. Int., 14, 449-455.

3) Barnes, H. R., Fiala, G., and Kwong, E. (1962): Methionine supplementation of processed soybeans in the rat. J. Nutr., 77, 278-284.

4) Borchers, R. (1962): Supplementary methionine requirement of weanling rats fed soybean oil meal rations. J. Nutr., 77, 309-311.

5) Eichholz, A. (1969): Fractions of the brush border. Fed. Proc., 28, 30-34.

6) Harper, A. E. (1959): Amino acid balance and imbalance. 1. Dietary level of protein and amino acid imbalance. J. Nutr., 68, 405-418.

7) Kimura, T., and Tahara, M. (1971): Effect of force-feeding diets lacking leucine, valine, isoleucine, threonine or methionine on amino acid catabolism in rats. J. Nutr., 101, 1646-1654.

8) Dahlqvist, A. (1964): Method for assay of intestinal disaccharidase. Anal. Biochem., 7, 18-25.

9) Kind, P. R. N., and King, E. J. (1954): Estimation of plasma phosphatase by determination of hydrolysed phenol with amino-antipyrine. J. Clin. Path., 7, 322-326.

10) Goldbarg, J. A., and Rutenburg, A. M. (1958): The colorimetric determination of leucine aminopeptidase in urine and serum of normal subjects and patients with the cancer and other diseases. Cancer, 11, 283-391.

11) Lowry, O. H., Rosebrough, N. J., Farr, A. L., and Randall, R. J. (1951): Protein measurement with the Folin phenol reagent. J. Biol. Chem., 193, 265-275.

12) Snedecor, G. W., and Cochran, W. C. (1967): Statistical Methods (Japanese Ed.), Iowa State University Press, Ames, Iowa, pp. 246-263.

13) Kimura, T., Shiosaka, S., Sakakibara, A., Matsuoka, A., and Yoshida, A. (1976): 
Effect of dietary amino acids and food intake on intestinal sucrase and leucine aminopeptidase activities of rats. Nutr. Rep. Int., 14, 657-670.

14) Kimura, T., Seto, A., and Yoshida, A. (1978): Effect of dietary amino acids and protein on jejunal disaccharidase and leucine aminopeptidase activities of rats. Nutr. Rep. Int., 16, 621-630.

15) Kimura, T., Kato, T., Tsukazaki, K., and Yoshida, A. (1979): Effect of diets supplemented with amino acids on intestinal sucrase and leucine aminopeptidase activities in rats. J. Nutr. Sci. Vitaminol., 25, 195-204.

16) Kimura, T., Seto, A., and Yoshida, A. (1978): Effect of diets on intestinal disaccharidase and leucineaminopeptidase activities in refed rats. J. Nutr., 108, 1087-1097.

17) Kimura, T., Furuta, H., Matsumoto, Y., and Yoshida, A. (1980): Ameliorating effect of dietary fiber on toxicities of chemicals added to a diet in the rat. J. Nutr., 110, 513-521.

18) Kimura, T., Iwata, E., Watanabe, K., and Yoshida, A. (1980): Effect of several chemicals added to a diet on intestinal enzyme activities of rats. J. Nutr. Sci. Vitaminol., 26, 483-496.

19) Kimura, T., Suzuki, S., and Yoshida, A. (1975): Effect of force-feeding of a valine-free diet on gastrointestinal function of rats. J. Nutr., 105, 257-265.

20) Kimura, T., Watanabe, K., Iwata, E., and Yoshida, A. (1981): Nutritional significance of intestinal sucrase activity in rats. J. Nutr. Sci. Vitaminol., 27, 485-488.

21) Liener, I. E., and Kakade, M. L. (1980): Nutritional significance of protease inhibitors, in Toxic Constituents of Plant Foodstuff, ed. by Liener, I. E., Academic Press, New York, pp. 40-51.

22) King, T. P. (1979): The nutritional toxicity of Phaseolus vulgaris lectins. Proc. Nutr. Soc., 38, 115-120. 